\title{
A Study of Liquidity and Interest Spread in Nepalese Cooperative Societies
}

\author{
Gyanendra Prasad Paudel ${ }^{1}$, Suvash Khanal ${ }^{2}$ \\ ${ }^{1}$ Nepal Merchant Cooperative Limited, Mahabouddha, Kathmandu, Nepal \\ ${ }^{2}$ Kist College of Management, Kathmandu, Nepal \\ Email address: \\ pgyanendrapd@gmail.com (G. P. Paudel), suvash2003@hotmail.com (S. Khanal)
}

\section{To cite this article:}

Gyanendra Prasad Paudel, Suvash Khanal. A Study of Liquidity and Interest Spread in Nepalese Cooperative Societies. International Journal of Economics, Finance and Management Sciences. Vol. 4, No. 6, 2016, pp. 321-330. doi: 10.11648/j.ijefm.20160406.11

Received: May 14, 2016; Accepted: June 6, 2016; Published: November 3, 2016

\begin{abstract}
The study has inquired about the determinants liquidity risk and investment risk which are measured by liquid assets to deposit ratio and average interest spread respectively of Nepalese cooperative society. We did descriptive, correlation, and regression analysis of five year accounting data of 126 cooperatives of Kathmandu valley. The descriptive statistics show a huge gap between cooperatives with respect to size, earnings, activities, etc., and suggest that the cooperatives should be ranked and categorized according to their size so that a prompt regulation can be imposed to them. The significant positive correlation of deposit with variables such as investment, net earnings, size, liquid assets, interest earnings, interest expenses, etc. suggested deposit marketing is the most crucial instrument to build up size, to generate revenue and earnings, to increases the activities, etc. The finding from regression analysis show that the big sized cooperatives are lacking proper amount of liquidity, and suffering from liquidity risk. Moreover, the finding also suggests that strong permanent capital base have significant positive influence on adequate liquidity of the cooperatives. Similarly, cooperatives having higher credit to deposit ratio have liquidity deficit. The spread model suggests that cooperative bearing higher amount of investment risk are utilizing its assets efficiently, and holding an adequate amount of long term source of fund. Similarly, a big sized cooperative has abided with lower degree of investment risk.
\end{abstract}

Keywords: Nepalese Cooperative Societies, Average Interest Spread, Liquidity Ratio

\section{Background}

A cooperative enterprise has its own norms and values. Cooperative society is a member based organization because it is established by the members for self-uplifting the socioeconomic status through mutual cooperation among the members. Moreover, "a cooperative society is an association of persons varying in number, who are grappling with the same economic difficulties and who voluntary associate on the basis of equal rights and obligations" [20]. Cooperative is voluntary organization, open to all willing to accept the responsibilities of membership, without gender, social, racial, political or religious discrimination. It is a democratic institution which is controlled by its members on the one member one vote basis. The most important is, it works for the sustainable development of its communities through policies approved by its own members [22]. In this regard, the people cooperate for a number of reasons. Thus, cooperatives have variety of operational dimensions and scopes. An agro-cooperative of farmers enable consolidation of fragmented land, investment in mechanization and irrigation, better bargaining power to buy seeds and fertilizers and to sell farm product to traders, to arrange for common storage, and to make comfortable credit from banks, etc., thereby improve the productivity and the incomes of the farmers [17]. A consumers-cooperative collectively purchase goods at wholesale prices, and in some cases, it owns factories, and becomes retailer as well as consumer [18].

In Nepal, numerous form of cooperatives-such as Saving and Credit (SC), Multipurpose (MC), Dairy, Agriculture, Fruits and Vegetables, Bee Keeping, Tea, Coffee, Consumers, Energy, Communication etc.- are operating today [13]. However, Nepalese people are using the form of social institutions such as Guthi (meaning is trust), Dhukuti 
(rotational financing based on bidding system, which is illegal today), Dharmabhakari (meaning is a big storage of grain, money, gold etc. made for the contribution of social work and personal borrowing), Paincho (meaning is borrowing mostly in kind), Parma (meaning is labor exchange), Saghu (meaning is community help among Magar community), Lhoba (meaning is community help among Gurung community), etc. from ancient period of time. Since, they were executing saving and credit functions, the operational features of those institutions were similar to the present day's cooperatives [28]. Cooperatives, mostly SC and $\mathrm{MC}$, provide financial services such as accepting deposits, providing loans, remitting money, etc. for their members [33, P. 2]. The data of mid July 2014 shows, the cooperative industry contributes more than $15 \%$ of total banking services, and more than $3 \%$ of total GDP of the country. Similarly, 31,177 cooperatives have collected 172,529 million rupees as deposit, and they have provided 154,631 million rupees as loan to their members. In addition to that, financial services provided by cooperatives have reached to $18 \%$. The industry has employed 54,143 persons directly, and millions of indirect employments have created through its financial supports to the sectors such as industry, firms, trading houses, small farmers, individual professionals, etc. [40]. Performance of enterprising cooperatives has increased due to capital access, risk sharing, community support, and so on.

The study aimed to seek the determinants of liquidity exposure and average interest spread of cooperatives of Nepal. We believe the study might be helpful to seek the position of liquidity risk and investment risk, to guide stakeholders for the implication of the findings, and to fulfill the research gap: for example -lacking study literatures in Nepalese cooperative industry. The remainder of the paper are presented as: the second and third sections have discussed about theoretical framework of liquidity and investment risk exposures, the fourth section has presented the role of government regarding the exposures, the fifth section has presented the adopted methods, the sixth, seventh and eighth sections have presented the data analysis and findings, and finally the ninth section has concluded the study.

\section{Role of Liquidity}

Nepalese cooperatives are doing fund intermediating business as depository institution like banks. It has been always a debate that how much amount of liquidity must be held by a depository institution. Since idle cash in vault does not earn and also deteriorates the value with the passing of time due to inflation, therefore holding high amount cash in vault is opportunity loss for a firm. However, holding low amount of cash in vault may delay in credit payment, decrease member confident, and reduce the goodwill of a cooperative. In this case, Baumol model suggest holding optimum level where opportunity cost of carrying cash is equal to fix conversion cost of investment securities [36]. Moreover, Liquidity risk has become more important after the recent financial crisis where markets went into liquidity crunch, and had to close down for few days [23]. Liquidity risk is the depositary institution's ability to meet its continuing obligations, including financing its assets. It is the risk of loss record or of failure to accomplish estimated liquidity needs resulting from the incapacity of cooperative banks to cope with the decrease of funding sources. Furthermore, liquidity has three notions, namely central bank liquidity, market liquidity and funding liquidity. Central bank liquidity is measured as the liquidity supplied to the economy by the central bank. Funding liquidity as the ability of bank or depository institutions to make agreed upon payments in a timely fashion [30]. Similarly, market liquidity incorporates volume, time and transaction costs of available liquidity in the market [16].

The global financial crises of 2007-08 elevated the concern of liquidity exposure and highlighted the essentiality for its assessment for the sound functioning of a depository institution or a financial system [6, 7]. The crisis showed a considerable study gap in the field of depository institutions' liquidity risk management. In response to this, Basel Committee issued new principles and guidelines on liquidity risk management highlighting the liquidity coverage ratio to measure the short-term liquidity risk, and the net stable funding ratio to measure the long-term liquidity risk [11]. But, during the crisis the credit unions and cooperative banks have carried out operation extraordinarily better than other financial institution since they are member based institution committed to strategic success than short term maximization of profit [38].

The empirical studies based on liquidity risk have shown a number of suggestions and direction about the liquidity exposure of depository institutions. Credit risk affects the health of the depositary institution's loan portfolio, which may affect depositary institution liquidity performance. The more the commercial banks are exposed to high-risk loans, the higher the accumulation of unpaid loans and the lower the liquidity [26]. Liquidity has strong positive impact on bank size, but it has strong negative impact on effectiveness of credit risk management [15]. On the contrary, bank size has negative influence with liquidity and bank specialization but positive with assets quality and gross domestic product of the nation [11]. The depository institutions having strong capital bases have a significant positive influence $[1,2,3,9,43]$ but the study done in Turkey shows a negative influence of permanent capital in liquidity performances [10]. Moreover, the study done in Central America found that preventive liquidity buffers are correlated with size, profitability, capitalization, and financial development [12]. Similarly, a study in bank's liquidity of seven countries found that bank's liquidity exposure is directly related with total capital ratio in Romania and Latvia, but inversely related in Bulgaria. Meanwhile, the liquidity exposure is directly related with return on equity and impaired loans to total loans ratio but inversely related with return on assets in the Czech banks [35].

Concerning all contradicting relationships between liquidity exposure and the variables above, thus, we are pointing a significant research question as: What kind of 
specific cooperative attribute has an association with the cooperative liquidity disclosure? In this case a research hypothesis has been formulated as:

Hypothesis I: There is no relationship between specific cooperative variables and the cooperative liquidity exposure.

\section{Average Interest Spread}

Average interest spread is the different between average earning rate and average paying rate of a depository institution. Earnings and paying rate is determined by the market, and thus are derived and moved along with change in market interest rate. Classical theory of interest rate says that market interest rate is determined by function of the demand of capital for aggregate investment and supply of capital through aggregate saving of an economy. A real investor like corporation demands the capital to the point where the marginal productivity of capital equals the marginal cost of capital. But the rate of return of a security is also determined by its inherited risk that can be measure by exposures such as liquidity, credibility, probability of default, maturity, etc. In case of increment in deposit or borrowing rate, there is no option that a depository institution should allocated its fund in higher rate which results consistency of average interest spread either the market interest rate increase or decrease. But, an increment in spread of a depository institution implies the risky allocation of available fund. Average interest spread is the measure of investment risk since higher spread implies risky investment decision done on loan and advance. In contrast, market concentration enables firms in the industry to borrow relatively in low rate and lend in high rate which increase the spread [5], and allows depository institution to fix their rate freely. This also allows depository institution to set lending rate at higher level and borrowing rate at lower level subject to given market power. As we are cooperative practitioner of Nepal, our experience has observed that credible and potential loan demander gives the first priority to commercial banks, second priority to development banks and finance company, and finally if a borrower does not have any option than only she or he comes to the door of cooperative. Moreover, the most surprising case is, neither a cooperative assures depositors/members by providing the guarantee of their deposits through insurance nor creates a risk bearing fund -such as loan loss provisionto recover existing bad debts [14]. The situation demands a rigorous study in average interest spread of Nepalese cooperative industry. The risk of a depository institution can be categorized as: default risk and exposure risk for investment decision. Default risk is the likelihood of failure of payment of debt in maturity. Such failure occurs when the economic value of the debtor's assets falls below the outstanding liabilities [32]. Exposure risk is the risk of experience measured insecurity during the collection of debt. Unfortunately, all outstanding debt of all lines of credit cannot be recovered. In this case, depository institution fixed a maximum limit of institution's risk exposure for consideration of taking investment decision [4].
A number of empirical studies have highlighted the interest spread of a depository institution in diverged prospective. The industrial relation studies predict that market structure may influence the spread [37]. Moreover, the spread is influences by inflation, deposit rate, credit rating, operational expenses to total assets ratio in negative direction but by loan loss provision and capital control in positive direction (ibid). A study about interest spread of banks in Pakistan found that interest-insensitivity of deposit supply had a positive influence on spread. But, the market concentration did not have significant influence in interest spread. Though regulator played some role in lowering the spread, emergence of alternate financial intermediaries increase the competition which played an important role to lowered the spread [25]. However, a next study insisted that the average interest margin is influenced by level of risk aversion of bank, market position and concentration, size of bank transaction, and the fluctuation of interest rates [21]. Similarly, a study done in interest spread of Kenya's banking industry suggested the positive relationship between the spread and variables such as size, return on assets, operating cost, market concentration, nonperforming loan ratio, etc., and negative relationship with liquidity exposure [42].

Concerning all contradicting relationships between spread and the variables above, thus, we are pointing a significant research question as: What are the specific cooperative attributes that have an association with the cooperative average interest spread? In this case, a hypothesis has been formulated as:

Hypothesis II: There is no relationship between cooperative variables and the cooperative average interest spread.

\section{Role of Government}

Cooperative is neither a stock company nor financial institution subjective to central bank's regulation. As financial intermediaries, it is creating credit by using members and depositors' money. With the increase in size of business, and in the absence of a strong regulator like central bank, security exchange board, etc., a number of financial cooperatives have been conducting activities which are against the basic cooperative principles. Some of the examples are: engaging in providing favorable loans to promoters without pledging collateral, mobilizing more than $50 \%$ of loans in unproductive sectors such as the housing sector, maintaining inadequate loan loss provisions, capitalizing interest earned as principal amount and mobilizing deposits higher than the required amount, etc. [29]. This has raised the loan loss and non-performing loan of the cooperative in significant level. Though cooperative can be struggled with liquidity problems caused by the increase loan loss and nonperforming assets in their balance sheets, it affects cooperatives' credit risk in first place and cooperatives' investment risk in second place [8]. Similarly, the recent fraud in cooperatives [24] has given negative impact to the overall financial system and reduced the public confident in cooperative business in Nepal. The key causes 
behind the crises are inefficient internal control system and weak regulatory supervision (ibid). A next study suggested that a cooperative society should educate their members and should provide training facilities to their staff for better performance and suggests the government to play a role of facilitator through monitoring [39]. Strategic Plan for Cooperative Development suggested of separate act for cooperatives acting as depository institution. The plan has listed the probable risk in the cooperatives such as boundary on the determination of competitive interest rate, difficulties on the insurance of deposit and loan amount, problems of maintained financial discipline, difficulties on the PEARLS monitoring system, and difficulties on the coordination for cooperative fund mobilization etc. [41]. National Cooperative Policy proposed a 'Deposit Guaranty Fund' for the security of deposited amount of the cooperative members, and effective monitoring system through loan information centre for the protection of investment done by the cooperatives [27].

\section{Methodology}

\subsection{Sampling and Data}

Table 1. No of Cooperatives in Kathmandu District at the End of 2009 July $15^{\text {th }}$.

\begin{tabular}{lll}
\hline Types & Total Size & Sample Size (\%) \\
\hline Saving and Credit (SC) & 864 & $91(10.53 \%)$ \\
Multipurpose (MC) & 358 & $35(9.78 \%)$ \\
Total (SC+MC) & 1222 & $126(10.31 \%)$ \\
Milk & 25 & - \\
Agriculture & 13 & - \\
Consumer & 4 & - \\
Health & 10 & - \\
Others & 15 & - \\
Total & 1289 & $126(9.78 \%)$ \\
\hline
\end{tabular}

Source: Statistical Report 2070, Division Cooperative Office, Kathmandu.

We used accounting data collected from the annual audit report of 91 savings and credits cooperatives (SC) and 35 multipurpose cooperatives (MC) from the Kathmandu valley located in central development region of Nepal. Most of the audited financial statements were collected from respective cooperatives, and other were collected from Ministry of Cooperative and Poverty Alleviation, Department of Cooperatives, National Cooperative Federation, National Cooperative Bank, Division Cooperative Offices, and District Cooperative Federation. The secondary data were collected for five year from 2009 to 2013 . A year 2013 is the proxy of Nepalese fiscal year $16^{\text {th }}$ July 2012 to $15^{\text {th }}$ July 2013, and rest of the sample years are also accredited in similar way. The sample size is 10.31 percent of total number of SC and MC for the base sample year i.e. 2009, and statistics are presented in the table 1 .

\subsection{Variables}

a) Liquid Assets (LA): The LA consists of cash in vaults, cash in bank, cash due from other financial institutions, money at call, and marketable securities.

b) Loan (Lon): The Lon is sum of loan portfolio. It consists of auto loan, real estate loan, agriculture loan, personal loan, commercial loan, overdraft loan, business loan, and all other loan portfolio. It is a major portion of total assets of a depository institution.

c) Other Investment (OInv): The OInv is the assets portfolio of a cooperative that consists of investment in financial securities such as corporate shares, debentures, government bond, treasury notes and bills, etc.

d) Total Assets (TA): The TA consists of four different form of assets portfolio of a cooperative such as cash and cash due from other financial institution, loan portfolio, investment securities, and other physical assets of a cooperative.

e) Deposit (Dep): The Dep is the total amount of current deposit, saving deposit, fixed deposit, and any other form of deposit accepted by a cooperative. It is a major portion of debt ratio of a depository institution.

f) Other Liabilities (OLia): The OLia is the non-deposit borrowing of a cooperative such as borrowed funds from cooperative bank, etc.

g) Earnings after Tax (EAT): The EAT is a net profit generated by a cooperative after deducting all operating expenses, interest expenses, and applicable income tax. The EAT is subject to the dividend distribution to the shareholder of the cooperative.

h) Interest Income (InI): An InI is the income generated from the interest earning assets i.e. Lon plus OInv. It is the main source of income for a depository institution.

i) Non-Interest Income (NII): The NII is the income other than interest income for a depository institution. Income such as service charges in deposit, membership, etc. are the NII.

j) Interest Expenses (IE): It is the main expenses of a depository institution. It is the amount paid to depositors and subordinated capital notes.

\subsection{Methods}

We analyzed the collected accounting data by financial ratios analysis, descriptive, correlation, and regression analysis. In order to measure the extent of liquidity and interest spread, ratios are estimated as in equ. 1 and equ. 2 respectively.

Liquidity Ratio

$$
(\mathrm{LR})=\frac{\mathrm{LA}_{\mathrm{it}}}{\mathrm{Dep}_{\mathrm{it}}}
$$

Average Interest Spread

$$
(\text { Spread })=\frac{\text { InI }_{\text {it }}}{\text { Lon }_{\text {it }}+\text { OInv }_{\text {it }}}-\frac{\mathrm{IE}_{\text {it }}}{\text { Dep }_{\text {it }}+\text { OLia }_{\text {it }}}
$$

The LR is calculated as ratio of LA to Dep, and Spread is calculated as average earning rate minus average paying rate. Moreover, the average earning rate is the ratio of total interest income to total interest earning assets i.e. total loan portfolio plus other investment securities. We have generated correlation coefficient matrix for the variables used in regression and descriptive analysis. As the theoretical framework for risk has not yet established, most studies 
include the firm specific variables when investigating a specific issue of risk [34]. In order to test the hypotheses I and II, in the first step, we estimated various financial ratios and regressed against the dependent variables, in the second step, we chose only those variables having significant influencing capacity to the dependent variables, and finally we formed functional relationship as in equ. 3 and 4.

$$
\begin{aligned}
& \mathrm{LR}_{\mathrm{it}}=\alpha+\beta_{1}\left[\frac{\mathrm{EAT}_{\mathrm{it}}}{\mathrm{InI}_{\mathrm{it}}+\mathrm{NII}_{\mathrm{it}}}\right]+\beta_{2}\left[1-\frac{\mathrm{Dep}_{\mathrm{it}}}{\mathrm{TA}_{\mathrm{it}}}\right]+\beta_{3}\left[\frac{\mathrm{InI}_{\mathrm{it}}+\mathrm{NII}}{\mathrm{TA}_{\mathrm{it}}}\right]+ \\
& \beta_{4}\left[\frac{\operatorname{Lon}_{\text {it }}}{\operatorname{Dep}_{\text {it }}}\right]+\beta_{5} \ln \operatorname{lA}_{\text {it }}+\mathrm{e}_{\mathrm{it}} \\
& \text { Spread }_{\text {it }}=\alpha+\beta_{1}\left[\frac{\mathrm{EAT}_{\mathrm{it}}}{\mathrm{InI}_{\mathrm{it}}+\mathrm{NII}_{\mathrm{it}}}\right]+\beta_{2}\left[1-\frac{\mathrm{Dep}_{\mathrm{it}}}{\mathrm{TA}_{\mathrm{it}}}\right]+\beta_{3}\left[\frac{\mathrm{InI}_{\mathrm{it}}+\mathrm{NII}_{\mathrm{it}}}{\mathrm{TA}_{\mathrm{it}}}\right]+ \\
& \beta_{4}\left[\frac{\operatorname{Lon}_{\text {it }}}{\operatorname{Dep}_{\text {it }}}\right]+\beta_{5} \ln T A_{i t}+e_{i t}
\end{aligned}
$$

Where, i represents the firm identification, and t represents the year identification.

$\left[\frac{\mathrm{EAT}_{\mathrm{it}}}{\mathrm{InI}_{\mathrm{it}}+\mathrm{NII}_{\mathrm{it}}}\right]=\mathrm{Net}$ profit margin (NPM): is a profitability ratio which is calculated as the ratio of EAT to total operating income.

$\left[1-\frac{\text { Dep }_{\text {it }}}{\mathrm{TA}_{\mathrm{it}}}\right]=$ Capital adequacy ratio (CAR): is calculated as ratio of total permanent capital to TA. Generally, in depositary institution, CAR is calculated as total permanent capital to risk weighted assets, but there is no provision for categorizing the capital and assets as Basel recommendation in cooperative of Nepal. In the vary case, we calculated permanent capital as TA minus core deposit and TA as proxy of total risk weighted assets.

$\left[\frac{\mathrm{InI}_{\mathrm{it}}+\mathrm{NII}_{\mathrm{it}}}{\mathrm{TA}_{\mathrm{it}}}\right]=$ Assets Utilization ratio (AU): is the efficiency ratio that measures how efficiently the cooperative utilizes asset to generate the total revenue.

$\left[\frac{\mathrm{Lon}_{\mathrm{it}}}{\mathrm{Dep}_{\mathrm{it}}}\right]=$ Credit to deposit ratio (CD): is also efficiency ratio and measures the amount of credit created per unit of deposit created by a cooperative.

InTA=Natural logarithm of TA which is the size proxy of a cooperative.

Now, the functions formulated in equ. 3 and equ. 4 are converted as equ. 5 and equ. 6 respectively.

$$
\begin{array}{r}
\mathrm{LR}_{\mathrm{it}}=\alpha+\beta_{1} \mathrm{NPM}_{\mathrm{it}}+\beta_{2} \mathrm{CAR}_{\mathrm{it}}+\beta_{3} \mathrm{AU}_{\mathrm{it}}+\beta_{4} \mathrm{CD}_{\mathrm{it}}+\beta_{5} \ln \mathrm{TA}_{\mathrm{it}}+\mathrm{e}_{\mathrm{i}} \\
\mathrm{Spread}_{\mathrm{it}}=\alpha+\beta_{1} \mathrm{NPM}_{\mathrm{it}}+\beta_{2} \mathrm{CAR}_{\mathrm{it}}+\beta_{3} \mathrm{AU}_{\mathrm{it}}+\beta_{4} \mathrm{CD}_{\mathrm{it}}+\beta_{5} \ln \mathrm{n} \mathrm{A}_{\mathrm{it}}+\mathrm{e}_{\mathrm{i}}
\end{array}
$$

We used SPSS 16.0 and Stata SE 10 computer applications to calculate correlation and regression coefficients, and descriptive statistics of financial ratios and accounting data are calculated by using Ms-excel 2007.

\section{Descriptive Analysis}

The descriptive statistics such as mean, median, standard deviation, etc. of variables used in study are presented in the table 2. The average liquidity measure i.e. LA is Rs 18160.9 thousand which is fluctuated by \pm Rs 37496.42 thousand in average (i.e. as suggested by standard deviation). The maximum and minimum LAs are Rs 376726 thousand and Rs44 thousand respectively. The average interest earnings and expenses are Rs 18426.31 thousand and Rs 15262.26 thousand respectively. Moreover the medians of the variables are Rs 4016.5 thousand and Rs 5908.5 thousand respectively which are smaller than average values, and implies the data is right skewed. The average deposit is Rs 124499.82 thousand, and the average credit created is Rs 110481.6 thousand respectively. And, the average fluctuations measured by standard deviation are Rs 326433.06 thousand and Rs 300492 thousand respectively. Moreover, the medians of the deposit and credit variables are Rs 35093 thousand and Rs 35002 thousand respectively which are greater than mean values, and implies the data is left skewed. The minimum deposit is Rs 180 thousand and maximum Rs 3,343,420 thousand. Again, the mean total asset for the sample is Rs 151,000 thousand. Standard deviation of mean assets is Rs 373, 426 thousand having minimum Rs 732 thousand and maximum Rs $3,798,954$ thousand. This shows a huge discrepancy of the cooperatives on the basis of size and activity. The descriptive statistics shows a huge gap between cooperatives with respect to size, earnings, activities, etc. suggesting unanimous cooperative regulation is not effective. For this, regulatory should categorize the cooperative such as A, B, C or in any other ways so that regulatory effectiveness can be increased. The cooperatives having small size, earnings or activities

\begin{tabular}{|c|c|c|c|c|c|c|c|c|c|c|}
\hline & Dep & Lon & OInv & OLia & InI & IE & LA & TA & EAT & NII \\
\hline Avg. & 124499.82 & 110481.6 & 8822.63 & 16823.63 & 18426.31 & 15262.26 & 18160.9 & 150780.67 & 1681.41 & 3454.62 \\
\hline Md. & 35093 & 35002 & 926 & 2438.5 & 5908.5 & 4016.5 & 5848 & 47712.5 & 376 & 948 \\
\hline SD & 326433.06 & 300492 & 24446.02 & 33307.99 & 49397.18 & 43974.69 & 37496.42 & 373426.2 & 7307.7 & 9825.74 \\
\hline $\operatorname{Max}$ & 3343420 & 3368359 & 255702 & 171157 & 548118 & 478498 & 376726 & 3798954 & 72277 & 134419 \\
\hline Min & 180 & 339 & 5 & 32 & 1 & 2 & 44 & 732 & -101934 & 1 \\
\hline $\mathrm{CV}$ & 2.62 & 2.72 & 2.77 & 1.98 & 2.68 & 2.88 & 2.06 & 2.48 & 4.35 & 2.84 \\
\hline $\mathrm{N}$ & 614 & 614 & 429 & 104 & 540 & 540 & 610 & 612 & 539 & 536 \\
\hline
\end{tabular}
cannot effort complex management system due to resources constraints, and cooperative having big size, earnings or activities may have adverse selection problem if systematic operation, risk and resources management are not applied.

Table 2. Descriptive statistics of variables used in the study (in thousand rupees).

(Avg.=Arithmetic average, Md.=Median, $\mathrm{SD}=$ Standard deviation, Max=Maximum, Min=Minimum, $\mathrm{CV}=\mathrm{Coefficient}$ of variation, $\mathrm{N}=\mathrm{No}$ of $\mathrm{Observations}$ ) 
The table 3 presents descriptive statistics of financial ratios such as LR, CAR, Spread, NPM, AU, and CD. A financial ratio (or accounting ratio) analysis is a process of judging in scale against two selected numerical values taken from a firm's financial statements. Some ratios are usually quoted in percentages, especially ratios that are usually or always less than 1 , while others are usually quoted as decimal numbers, especially ratios that are usually more than 1 . Ratios generally are not useful unless they are benchmarked against something else, like past performance or another firm. Financial ratios allow for comparisons between firms, between industries, between different time periods for same firm, and between a single firm and its industry average. Thus, the ratios of firms in different industries, which face different risks, capital requirements, and competition, are usually hard to compare [19].

Table 3. Descriptive statistics of financial ratios (in\%).

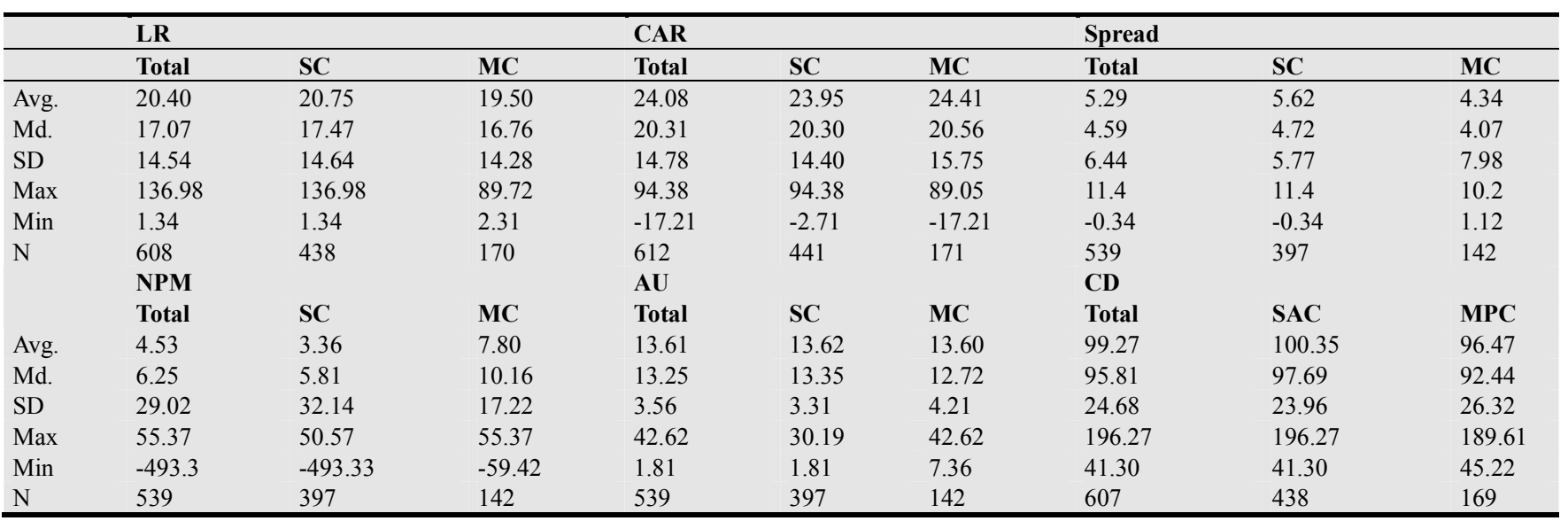

(Avg. $=$ Arithmetic average, $\mathrm{Md} .=$ Median, $\mathrm{SD}=$ Standard deviation, Max=Maximum, Min=Minimum, N=No of Observations)

Similarly, the average LR of the sample was $20.40 \%$, and suggests in average cooperative had $20.40 \%$ liquid assets to pay day to day liquidity demanded by depositors. Higher amount of LR stands higher ability of paying debt but low degree of efficiency and profitability due to opportunity cost of liquidity. Likewise, standard deviation of LR was 14.54\%, and shows in average LR of cooperative has deviated by $\pm 14.54 \%$ from mean value of given set of data. The maximum LR with in sample was $136.98 \%$, and minimum LR with in sample was $1.34 \%$ having range of $135.64 \%$ score. The results observed here is due to low amount of deposit collection done by some cooperatives than equity amount contributed by shareholders. The median score is partition value that divides to two equal upper and lower parts of a set of data. For entire sample, $50 \%$ of cooperatives were operating above $17.07 \% \mathrm{LR}$ scores. If we compare the descriptive scores of SC and MC, SC had higher LR than $\mathrm{MC}$. This suggests $\mathrm{MC}$ is operating with more liquidity risk than SC. The liquid assets to total deposit ratio of Nepalese commercial bank is $18.81 \%$ and $18.2 \%$ for 2009 and 2013 respectively [31], and the fact suggests in average cooperatives are holding higher liquidity than commercial bank. The average Spread of the sample suggests an average difference in earning and paying rate of cooperative was $5.29 \%$. The standard deviation shows in average Spread of cooperative may deviate by $6.44 \%$ either in positive or in negative direction. The maximum Spread of the industry with in sample was $11.4 \%$, and minimum Spread score of the industry with in sample was $-0.34 \%$. This suggests cooperatives are taking much risky decision while making borrowing and lending activities. The average interest spread of SC seems to be higher than MC suggesting SC is taking higher investment risk than MC.

\section{Correlation Analysis}

A correlation coefficient measures the strength and direction of the linear relationship between two variables but not the causality between them. The table 4 and table 5 represent the correlation matrixes between the secondary variables and estimated ratio variables respectively.

From the table 4, the credit is perfectly correlated with deposit since correlation coefficient between loan and deposit is 0.984 . The score is significant enough to define the linear relationship between loan and deposit since its $t$ score is significant at $1 \%$. The logical assumption behind it also true that if a cooperative collects deposit than only those are converted into loan. Deposit and loan are significantly correlated with OInv, OLia, EAT, TA, LA, II, NII, and IE. This suggests deposit marketing is the most important factor to build up size, to earn revenue, and to increase activities and earnings of cooperative since deposits are converted into loan and generated the earnings and revenue to a depository institution. Thus, total revenue and total expenses are also perfectly correlated to Lon and Dep in positive direction. Since IE and II are associated with size of deposit, they are also correlated with each other significantly in positive direction. The EAT is significantly correlated with OInv, OLia, II, IE, TA, and NII in positive direction since correlation coefficients between the EAT and the variables are $0.346,0.376,0.576,0.568,0.576$, and 0.406 respectively. This suggests to increase in the investment, interest earnings, 
size, and activities in order to improve the profitability of bank. The LA is also correlated in positive direction with all selected variables for the study, since, the increment in activities such as deposit collection, investment, size and so on increase the figures of firm's financial affairs.

Table 4. Pearson Correlation Statistics of Secondary Data Variables.

\begin{tabular}{|c|c|c|c|c|c|c|c|c|c|c|}
\hline & & Dep & Lon & OInv & OLia & InI & IE & LA & TA & EAT \\
\hline \multirow{2}{*}{ Lon } & $r$ & $0.984 * *$ & & & & & & & & \\
\hline & $\mathrm{N}$ & 614 & & & & & & & & \\
\hline \multirow{2}{*}{ OInv } & $r$ & $0.545^{* *}$ & $0.445 * *$ & & & & & & & \\
\hline & $\mathrm{N}$ & 429 & 429 & & & & & & & \\
\hline \multirow{2}{*}{ OLia } & $r$ & $0.226^{*}$ & $0.352 * *$ & 0.156 & & & & & & \\
\hline & $\mathrm{N}$ & 104 & 104 & 88 & & & & & & \\
\hline \multirow{2}{*}{ InI } & $\mathrm{r}$ & $0.968 * *$ & $0.987 * *$ & $0.412 * *$ & $0.391 * *$ & & & & & \\
\hline & $\mathrm{N}$ & 539 & 539 & 404 & 92 & & & & & \\
\hline \multirow{2}{*}{ IE } & $\mathrm{r}$ & $0.984 * *$ & $0.982 * *$ & $0.502 * *$ & 0.165 & $0.986 * *$ & & & & \\
\hline & $\mathrm{N}$ & 539 & 539 & 404 & 92 & 540 & & & & \\
\hline \multirow{2}{*}{ LA } & $\mathrm{r}$ & $0.831 * *$ & $0.809 * *$ & $0.476 * *$ & $0.449 * *$ & $0.816^{* *}$ & $0.817 * *$ & & & \\
\hline & $\mathrm{N}$ & 608 & 608 & 428 & 104 & 534 & 534 & & & \\
\hline \multirow{2}{*}{ TA } & $\mathrm{r}$ & $0.996 * *$ & $0.986^{* *}$ & $0.544 * *$ & $0.354 * *$ & $0.975 * *$ & $0.984 * *$ & $0.843 * *$ & & \\
\hline & $\mathrm{N}$ & 612 & 612 & 428 & 104 & 539 & 539 & 607 & & \\
\hline \multirow{2}{*}{ EAT } & $\mathrm{r}$ & $0.561 * *$ & $0.569 * *$ & $0.346^{* *}$ & $0.376 * *$ & $0.576^{* *}$ & $0.568 * *$ & $0.438 * *$ & $0.576^{* *}$ & \\
\hline & $\mathrm{N}$ & 538 & 538 & 403 & 92 & 539 & 539 & 533 & 538 & \\
\hline \multirow{2}{*}{ NII } & $r$ & $0.604 * *$ & $0.496 * *$ & $0.731 * *$ & 0.128 & $0.451 * *$ & $0.549 * *$ & $0.451 * *$ & $0.597 * *$ & $0.406 * *$ \\
\hline & $\mathrm{N}$ & 535 & 535 & 401 & 91 & 536 & 536 & 530 & 535 & 535 \\
\hline
\end{tabular}

(Dep=Deposit; Lon=Loan; OInv=Other Investment; OLia=Other liabilities; II=Interest Income; NII=Non Interest Income; IE=Interest Expenses; LA=Liquid Assets; TA=Total Assets; EAT=Earnings After Tax; $\mathrm{N}=$ no of observation; $\mathrm{r}=$ Pearson Correlation; **Correlation is significant at the 0.01 level (2-tailed); *Correlation is significant at the 0.05 level (2-tailed).)

Table 5. Pearson Correlation Statistics of Regression Variables.

\begin{tabular}{|c|c|c|c|c|c|c|c|}
\hline & & NPM & LR & CAR & Spread & $\mathbf{A U}$ & CD \\
\hline \multirow{2}{*}{ LR } & $r$ & $-0.108^{*}$ & & & & & \\
\hline & $\mathrm{N}$ & 533 & & & & & \\
\hline \multirow{2}{*}{ CAR } & $\mathrm{r}$ & -0.044 & $0.305 * *$ & & & & \\
\hline & $\mathrm{N}$ & 538 & 607 & & & & \\
\hline \multirow{2}{*}{ Spread } & $\mathrm{r}$ & $0.127 * *$ & $0.187 * *$ & $0.156 * *$ & & & \\
\hline & $\mathrm{N}$ & 538 & 534 & 539 & & & \\
\hline $\mathrm{AU}$ & $\mathrm{r}$ & $0.197 * *$ & $0.162 * *$ & $0.162 * *$ & $0.450 * *$ & & \\
\hline \multirow{2}{*}{$\mathrm{CD}$} & $\mathrm{r}$ & 0.085 & -0.03 & $0.699 * *$ & $0.095 *$ & $0.157 * *$ & \\
\hline & $\mathrm{N}$ & 532 & 601 & 605 & 533 & 533 & \\
\hline \multirow{2}{*}{ InTA } & $\mathrm{r}$ & $0.227 * *$ & $-0.210 * *$ & $-0.319 * *$ & $-0.219 * *$ & $-0.233 * *$ & $-0.337 * *$ \\
\hline & $\mathrm{N}$ & 538 & 607 & 612 & 539 & 539 & 605 \\
\hline
\end{tabular}

$\left(\mathrm{N}=\right.$ no of observation; $\mathrm{r}=$ Pearson Correlation; ** Correlation is significant at the 0.01 level (2-tailed); ${ }^{*}$ Correlation is significant at the 0.05 level $(2$-tailed).

From the table 5 , the correlation coefficient between NPM and LRis -0.108 which is significant at $5 \%$, and implies poor degree of linear negative correlation between them. This suggests higher LR i.e. higher cash in vault resulting higher opportunity cost, and therefore, has decreased profitability of the cooperative. The correlation coefficient between CAR and LR is 0.305 , and its $t$ score is significant at $1 \%$ suggesting cooperatives having higher capital base have adequate liquidity as well. The linear relationship between Spread and variables such as LR and AU is positive. The InTA is negatively correlated with LR, CAR, Spread, AU, and $\mathrm{CD}$. This suggests the big sized cooperatives have higher investment and liquidity risk exposures and lower efficiency.

\section{Regression Analysis}

In this section, we have presented results of regression equations estimated in method part of methodology section.
In order to estimate OLS and GLS statistics, we have included additional variables in each forward steps so that variation on causation aptitude of estimator could be tapped. The OLS and GLS statistics are presented in the table 6 for LR model and in the table 7 for Spread model. The results from OLS and GLS seem to be consistent in most of the cases suggesting the year and firm identification have very poor or no influence for the estimation of regression statistics.

From the table 6, coefficient of determination for the first step regression is 0.044 indicating influencing capacity of InTA for dependent variable LR is $4.4 \%$, and remaining $95.6 \%$ is by other factors. The model's $\mathrm{F}$ and Chi square scores and predicting variables't scores are significant at $0 \%$. Indicating, in overall model and variables are significant enough to define causality between explanatory and dependent variables. Moreover, the negative direction suggested by model shows the big sized cooperatives are 
lacking proper amount of liquidity, and suffering from liquidity risk. The relationship between size and liquidity exposure of our study is consistent with [11] study, but inconsistent with [15] study. Furthermore, adding CAR variable in the step 2 , the predicting capacity of model has increased since $\mathrm{R}$ square increased to $10.7 \%$. In contrast to the role of InTA, role of CAR in model is positive to predict LR. In addition to that, the beta coefficient of CAR implies that an increase in $1 \%$ CAR results $0.26 \%$ increase in LR of cooperative keeping effects of other variable constant. Similarly, supporting the argument made in correlation analysis, cooperatives having strong capital base have substantial liquidity too. The relationship between LR and CAR suggested by our study is consistent with the previous studies such as [1, 2, 3, 9, 43], but inconsistent with study such as [10]. Furthermore, adding CD variable in step 3 analysis, predicting capacity of model has become strongest since $\mathrm{R}$ square value is $20.8 \%$ which is greater than $\mathrm{R}$ square of step 1, step 2, and step 4 . The beta coefficient of CD implies that if CD ratio is increased by $1 \% \mathrm{LR}$ of cooperative would decreased by $0.28 \%$ suggesting cooperatives having higher $\mathrm{CD}$ ratio (i.e. investing more portion of deposit in loan portfolio) also have liquidity deficit. Though $\mathrm{t}$ score of beta coefficient of AU variable in step 4 is significant at $1 \%$ and $0 \%$ in OLS and GLS estimates respectively, it has decreased the F score, chi square score and R square. This suggests the variable $\mathrm{AU}$ is collinear with either of explanatory variable (s) in the model, and caused disturbance in functional operation of the model.

Table 6. LR Model: Stepwise Regression Statistics.

\begin{tabular}{|c|c|c|c|c|c|c|c|c|}
\hline & Step 1 & & Step 2 & & Step 3 & & Step 4 & \\
\hline & OLS & GLS & OLS & GLS & OLS & GLS & OLS & GLS \\
\hline \multirow{2}{*}{$\mathrm{AU}$} & & & & & & & 0.513 & 0.51 \\
\hline & & & & & & & $3.09 * *$ & $3.1 * * *$ \\
\hline \multirow{2}{*}{$\mathrm{CD}$} & & & & & -0.282 & -0.28 & -0.246 & -0.25 \\
\hline & & & & & $-9.3 * * *$ & $-9.34 * * *$ & $-7.516^{* * *}$ & $-7.55 * * *$ \\
\hline \multirow{2}{*}{ CAR } & & & 0.264 & 0.26 & 0.582 & 0.58 & 0.441 & 0.44 \\
\hline & & & $6.53 * * *$ & $6.55^{* * *}$ & $10.83 * * *$ & $10.86^{* * *}$ & $7.336 * * *$ & $-7.37 * * *$ \\
\hline \multirow{2}{*}{ InTA } & -2.163 & -2.16 & -1.283 & -1.28 & -1.973 & -1.97 & -2.028 & -2.03 \\
\hline & $-5.28 * * *$ & $-5.28 * * *$ & $-3.062 * *$ & $-3.07 * * *$ & $-4.9 * * *$ & $-4.91 * * *$ & $-4.589 * * *$ & $-4.61 * * *$ \\
\hline \multirow{2}{*}{ Con. } & 58.8 & 58.80 & 36.832 & 36.83 & 69.59 & 8.14 & 63.55 & 63.55 \\
\hline & $8.05^{* * *}$ & $8.06 * * *$ & $1.708 * * *$ & $4.72 * * *$ & $8.525 * * *$ & $8.55 * * *$ & $6.809 * * *$ & $6.84 * * *$ \\
\hline $\mathrm{F} / \mathrm{X}^{2}$ & $27.82 * * *$ & $27.92 * * *$ & $36.21 * * *$ & $72.78 * * *$ & $52.13 * * *$ & $157.43 * * *$ & $26.08 * * *$ & $105.31 * * *$ \\
\hline $\mathrm{R}^{2}$ & 0.044 & & 0.107 & & 0.208 & & 0.166 & \\
\hline $\mathrm{N}$ & 605 & & 596 & & 596 & & 523 & \\
\hline
\end{tabular}

$\left(\right.$ Con. $=$ Constant predictors; $\mathrm{R}^{2}=$ Coefficient of Determinates; $* * *$ Significant at the $0 \% ; *$ Significant at the $1 \%$; and $*$ Significant at the $5 \%$ )

This table shows statistics of four-step OLS and GLS estimates of 126 Nepalese cooperative societies for the unbalanced panel data of entire period pooling cross-sectional and time series data from 2009 to 2013 . LR is dependent variable for all models; Variables in leftmost column are included variables in each respective step; Data are extracted from audited annual reports of respective cooperatives.

Table 7. Spread Model: Stepwise Regression Statistics.

\begin{tabular}{|c|c|c|c|c|c|c|c|c|}
\hline & Step 1 & & Step 2 & & Step 3 & & Step 4 & \\
\hline & OLS & GLS & OLS & GLS & OLS & GLS & OLS & GLS \\
\hline \multirow{2}{*}{ NPM } & & & & & & & 0.019 & 0.02 \\
\hline & & & & & & & $2.681 *$ & $2.70 * * *$ \\
\hline \multirow{2}{*}{ InTA } & & & & & -0.383 & -0.38 & -0.51 & -0.505 \\
\hline & & & & & $-2.6^{*}$ & $-2.56^{* * *}$ & $-3.24 * *$ & $-3.26 * * *$ \\
\hline \multirow{2}{*}{ CD } & & & -0.067 & -0.067 & -0.07 & -0.07 & -0.076 & -0.076 \\
\hline & & & $-6.016^{* * *}$ & $-6.04 * * *$ & $-6.28 * * *$ & $-6.31 * * *$ & $-6.72 * * *$ & $-6.76 * * *$ \\
\hline \multirow{2}{*}{ CAR } & 0.039 & 0.039 & 0.175 & 0.175 & 0.168 & 0.17 & 0.174 & 0.17 \\
\hline & $2.21 * *$ & $2.21 * * *$ & $8.73 * * *$ & 8.76 *** & 8.36 *** & $8.39 * * *$ & $8.66 * * *$ & $8.71 * * *$ \\
\hline \multirow{2}{*}{$\mathrm{AU}$} & 0.788 & 0.788 & 0.876 & 0.88 & 0.851 & 0.85 & 0.811 & 0.81 \\
\hline & $11.19 * * *$ & $11.22 * * *$ & $15.7 * * *$ & $15.76^{* * *}$ & $15.1 * * *$ & $15.18 * * *$ & $13.96 * * *$ & $14.04 * * *$ \\
\hline \multirow{2}{*}{ Con. } & -6.37 & -6.374 & -4.157 & -4.16 & 3.47 & 3.47 & 6.55 & 6.55 \\
\hline & $-6.29 * * *$ & $-6.31 * * *$ & $-3.95 * * *$ & $-3.96 * * *$ & 1.996 & 1.1 & 1.96 & $1.97 * * *$ \\
\hline $\mathrm{F} / \mathrm{X}^{2}$ & $70.94 * * *$ & $142.68 * * *$ & $110.64 * * *$ & $334.45 * * *$ & $85.47 * * *$ & $345.11 * *$ & $70.7 * * *$ & $335.5 * * *$ \\
\hline $\mathrm{R}^{2}$ & 0.209 & & 0.386 & & 0.393 & & 0.402 & \\
\hline $\mathrm{N}$ & 538 & & 529 & & 528 & & 526 & \\
\hline
\end{tabular}

(Con. $=$ Constant predictors; $\mathrm{R}^{2}=$ Coefficient of Determinates; $* * *$ Significant at the $0 \% ; *$ Significant at the $1 \%$; and $*$ Significant at the $5 \%$ )

This table shows statistics of four-step OLS and GLS estimates of 126 Nepalese cooperative societies for the 
unbalanced panel data of entire period pooling crosssectional and time series data from 2009 to 2013. Spread is dependent variable for all models; Variables in leftmost column are included variables in each respective step; Data are extracted from audited annual reports of respective cooperatives.

From the table 7, the $\mathrm{F}$ and Chi square scores of the step 1 analysis of Spread model are 70.94 and 142.68 respectively, and both of them are significant at $0 \%$. This suggests the model is significant enough to predict Spread variable by explanatory variables AU and CAR. The beta coefficients of $\mathrm{AU}$ and CAR variables implies an increase in $1 \%$ the variables individually could result individual increase in $0.788 \%$ and $0.032 \%$ average interest spread respectively keeping other effects constant. The positive relationships between the explanatory and explained variables indicate that the cooperative taking higher investment risk has utilized its assets efficiently to produce total revenue and has held adequate amount of permanent capital. Furthermore, adding independent variable $\mathrm{CD}$ in step 2, influencing power of explanatory variables has increased since model's $\mathrm{R}$ square value is $38.6 \%$. The beta coefficient of $\mathrm{CD}$ is negative suggesting a $0.38 \%$ decrease in average interest spread due to an increase in $1 \%$ CD keeping effects of other explanatory variables constant. Similarly, the results shown by the step 4 model suggests that an increase in $1 \%$ profit margin influence the investment risk by $0.2 \%$ increment. Furthermore, the negative beta coefficient of InTA suggests the big sized cooperatives have lower degree of investment risk. The relationship between average interest spread and size suggested by our study is inconsistent with [42] study done in Kenya.

\section{Conclusion}

We aimed to inquire about the determinants of exposure of liquidity and average interest spread in Nepalese cooperative society. The recent global financial crises has uplifted concern of liquidity crises and figured out the important of its evaluation for the healthy operation of an intermediary firm or an economy. Furthermore, the importance of average interest spread has been highlighted in different ways by the past studies.

Though a Nepalese cooperative is creating credit through members and depositors' money, it is neither a stock company nor financial institutions subjective to central bank's regulation. The descriptive statistics suggested a huge gap between cooperatives with respect to size, earnings, activities, etc. And, for a prompt regulation, cooperatives should be categorized-for example as class of A, B, C, etc.-according to their size. Since a small sized cooperative cannot effort complex record keeping and processing system due to its resources constraint, and a big sized cooperative may be suffered from adverse selection problem if systematic record keeping and other management system are not applied. The significant positive correlation with deposit and loan and other variables such as investment, net earnings, size, liquid assets, interest earnings, interest expenses, etc. suggested deposit marketing is the most crucial instrument to build up size, to generate revenue and earnings, to increases the activities, etc. The finding from regression analysis show that the big sized cooperatives are lacking proper amount of liquidity, and suffering from liquidity risk. The finding is supported by [11] study, but not supported by the [15] study. Moreover, the finding also suggests that strong permanent capital base have significant positive influence on adequate liquidity of cooperatives. In this case, the finding from the studies such as $[1,2,3,9,43]$ is consistent, and the finding from [10] is inconsistent with the present study. Similarly, cooperatives having higher $\mathrm{CD}$ ratio have liquidity deficit. The spread model suggests that cooperative bearing higher amount of investment risk are utilizing its assets efficiently, and holding an adequate amount long term source of fund. Similarly, a big sized cooperative has abided with lower degree of investment risk which is conflicting with finding of [42] study.

\section{References}

[1] Abusharba, M. T., Triyuwono, I., Ismail, M., \& Rahman, A. F. (2013). Determinants of Capital Adequacy Ratio (CAR) in Indonesian Islamic Commercial Banks. Global Review of Accounting and Finance, Vol. 4. No. 1. March. Pp. 159-170.

[2] Al-Tamimi, K. A. M., \& Obeidat, S. F. (2013). Determinants of Capital Adequacy in Commercial Banks of Jordan an Empirical Study. International Journal of Academic Research in Economics and Management Sciences July 2013, Vol. 2, No. 4 ISSN: 2222-6990.

[3] Apsal, P. K., \& Nazneen, A. (2014). An Empirical Analysis of Capital Adequacy in the Indian Private Sector Banks. American Journal of Research Communication.

[4] Arunkumar \& Kotreshwar, (2006). Risk Management in Commercial Banks (A Case Study of Public and Private Sector Banks). Jurnal Akuntansi Diakses.

[5] Bain, J. S. (1951). Relation of Profit Rate to Industry Concentration: American Manufacturing, 1936-1940. The Quarterly Journal of Economics. Vol. 65, No. 3 (Aug.), pp. 293-324.

[6] Bank for International Settlements, (2010). Basel III: International framework for liquidity risk measurement, standards and monitoring, Basel Committee on Banking Supervision, Basel.

[7] Bank for International Settlements, (2013). Basel III: The Liquidity Coverage Ratio and liquidity risk monitoring tools, Basel Committee on Banking Supervision, Basel.

[8] Bashyal, R. (2005). Impact of Microcredit Program on Poverty Alleviation in Nepal. An Unpublished PhD Thesis. Kathmandu: Tribhuvan University. Bateni et al., 2014;

[9] Bateni, L., Vakilifard, H., \& Asghari, F. (2014). The Influential Factors on Capital Adequacy Ratio in Iranian Banks, International Journal of Economics and Finance; Vol. 6, No. 11.

[10] Büyükşalvarc1, A., \& Abdioğlu, H. (2011). Determinants of Capital Adequacy Ratio in Turkish Banks: A Panel Data Analysis, African Journal of Business Management Vol. 5 (27), pp. 11199-11209. 
[11] Cucinelli, D. (2013). The Determinants of Bank Liquidity Risk within the Context ofEuro Area. Interdisciplinary Journal of Research in Business. Vol. 2, Issue. 10, pp. 51- 64.

[12] Deléchat, C., Henao, C., Muthoora, P., \& Vtyurina, S. (2012). The Determinants of Banks' Liquidity Buffers in Central America. International Monetary Fund, WP/12/301.

[13] DEOC online, http://www.deoc.gov.np/en/content.php?id=220. (Accessed 29. 09. 2015).

[14] Dhakal, S. P. (2012). Cooperative Economy for Socio Economic Development. Kathmandu: Sulabh DhakalDivision Cooperative Office, Kathmandu. Statistical Report 2070,

[15] Elian, K. A. (2013). Effectiveness of Credit Risk Management of Saudi Banks in the Light of Global Financial Crisis: A Qualitative Study. Asian Transactions on Basic and Applied Sciences (ATBAS ISSN: 2221-4291) Volume 03 Issue 02

[16] Fernandez, F. A. (1999). Liquidity Risk: New Approaches to Measurement and Monitoring. Securities Industry Association Working Paper.

[17] Gertler, M. (2001). Rural Co-operatives and Sustainable Development, Saskatoon SK: Centre for the Study of Cooperatives, University of Saskatchewan.

[18] Gide, C. (1921). Consumers' Co-operative Societies, Manchester: The Co-operative Union Limited, p. 122, ISBN 1-116-75261-1

[19] Groppelli, A. A.,\&Nikbakht, E. (2000). Finance, $4^{\text {th }}$ ed. Barron's Educational Series, Inc. p. 433. ISBN 0-7641-1275-9.

[20] Henrÿ, H. (2005). Guidelines for Cooperative Legislation, second revised edition Geneva, International Labour Office, ISBN 92-2-117210-4.

[21] Ho, T., \& A. Saunders (1981). The Determinants of Bank Interest Margins: Theory and Empirical Evidence. The Journal of Financial and Quantitative Analysis Vol. 16, proceedings of $16^{\text {th }}$ Annual Conference of the Western Financial Association, pp. 581-600.

[22] ICA. (1995). On-Line Conference on Cooperative Principles, Sept. 1995. International Cooperative Information Centre. ICA/UWCC.

[23] Indian Institute of Banking and Finance. (2011). Risk Management, An Overview. Mumbai: Macmillan.

[24] Karki, G. B., S. R. Upreti, \& S. R. Mathema. (2013). "Progress Report". Investigation Commission of Distress cooperatives doing saving and credit transaction, 2070.

[25] Khawaja, M. I., \& Din, M. (2007). Determinants of Interest Spread in Pakistan. The Pakistan Development Review 46: 2, pp. 129-143. Available at

http://core.ac.uk/download/pdf/6422760.pdf (Accessed 3. 10. 2015)

[26] Megeid, N. S. A. (2013). Impact of Effective Credit Risk Management on Commercial Banks Liquidity Performance: Case of Egypt International Journal of Accounting and Financial Management Research (IJAFMR) Vol. 3, Issue 2.

[27] National Cooperative Policy, (2013). Ministry of Cooperatives and Poverty Alleviation, Department of Cooperatives. Baneshor Kathmandu.

[28] NCF, (2010). Strategic Plan for Cooperative Development
(2009 - 2012). National Cooperative Federation, Nepal (NCF/N): Kathmandu.

[29] NEF, (2013). NEFSSEARCH, A Special Report in Financial Fraud in Nepal, Financial Frauds- Mitigating Risks, Nepal Economic Forum (NEF)

[30] Nikolaou, K. (2009). Liquidity (Risk) Concept: Definitions and Interactions. European Central Bank, Euro-System. Working Paper Series No 1008.

[31] NRB, (2014). Banking and Financial Statistics Mid-July, 2014 Np. 60. Nepal Rastra Bank. Bank and Financial Institution Regulation Department. Statistics Division.

[32] Pânzaru, S. (2011). Strategic Management in Commercial Banks, Review of General Management, Vol. 14 Issue 2, pp. 122-129.

[33] Paudel, G. P., \& Khanal, S. (2015). Determinants of Capital Adequacy Ratio (CAR) in Nepalese Cooperative Societies. Available at SSRN: http://ssrn.com/abstract $=2647541$. (Accessed 29. 09. 2015).

[34] Rahman, A. A., \& Shahida, S. (2010). Credit Risk and Financing Structure of Malaysian Islamic Banks. Journal of Economic Cooperation and Development, 31, 83-105.

[35] Roman, A., \& Sargu, A. C. (2015). The impact of bankspecific factors on the commercial banks liquidity: empirical evidence from CEE countries. Procedia Economics and Finance, 20, 571-579. ( $7^{\text {th }}$ International Conference on Globalization and Higher Education in Economics and Business Administration, GEBA, 2013).

[36] Ross S., Hillier D., Westerfield R., Jaffe J., \& Jordan B. (2012). Corporate finance, Cash Management., 27 McGrawHill Chap 27, Pp. 745-759.

[37] Samuel, \& Valderrama (2006). The Monetary Policy Regime and Banking Spreads in Barbados. (IMF Working Paper, $\mathrm{WP} / 06 / 211)$.

[38] Senious, C. (2009). Cooperative Banks, Credit Unions and the Financial Crisis. Prepared for the United Nations Expert Group Meeting on Cooperatives April 28-30, 2009, New York.

[39] Sharma, K. R. (2012). Saving and Credit Cooperative as a Poverty Reduction Program: A Case Study of Rupandehi District. An unpublished PhD Thesis. Nainital: Kumaun University.

[40] Statistics of Cooperative Enterprises, (2014). Government of Nepal, Ministry of Cooperatives and Poverty Alleviation. Department of Cooperative.

[41] Strategic Plan for Cooperative Development (2012 - 2016). National Cooperative Federation, Nepal (NCF/N): Kathmandu.

[42] Were, M. \& Wambua, J. (2013). Assessing the determinants of interest rate spread of commercial banks in Kenya: An empirical investigation KBA. Working Paper Series, WPS/01/13. Centre for Research on Financial Markets and Policy.

[43] Williams, H. T. (2011). Determinants of capital adequacy in the Banking Sub-Sector of the Nigeria Economy: Efficacy of Camels. (A Model Specification with Co-Integration Analysis). International Journal of Academic Research in Business and Social Sciences, Vol. 1, No. 3, pp. 233-248. 